\title{
The Impact of Online Learning Policy during the Covid-19 Pandemic: An Analysis of Islamic Education
}

\author{
M. Syahran Jailani \\ UIN Sulthan Thaha Saifudin Jambi \\ Email:m.syahran@uinjambi.ac.id
}

\section{Sutrisno}

UIN Sulthan Thaha Saifuddin Jambi

Email: tryznoswtsi@gmail.com

\section{Manazil Siddik \\ UIN Sulthan Thaha Saifuddin Jambi \\ Email: manazilsiddik@gmail.com}

\begin{abstract}
This article aims to analyze how the online learning policy launched by the government during the Covid-19 pandemic impact on Islamic religious education. The analysis approach used is a library research and research results related to online learning policies during the Covid 19 period. This research findings show that the implementation of online learning is still far from what is expected, despite all its advantages and disadvantages. The dynamics experienced either by educators, students or parents is a challenge for the government. The collaboration of educational institutions, students and parents is essential for the success of this program. The impact of online learning in the context of Islamic education is very influential in the process of ordering character and inculcating Islamic values. The stakeholders and all policy makers must encourage this policy so that the learning transformation process can be carried out properly, by utilizing and maximizing the presence of information and communication technology availability.
\end{abstract}

Keywords: online learning, covid-19 and Islamic education.

Abstrak: Artikel ini bertujuan menganalisis bagaimana dampak kebijakan pembelajaran jarak jauh yang dicanangkan pemerintah di masa pandemi covid-19 pada pendidikan agama Islam. Analisis dengan menggunakan kajian literaturliteratur kepustakaan dan hasil penelitian yang terkait dengan kebijakan pembelajaran jarak jauh jauh di masa Covid 19. Hasil analisis, bahwa implementasi kebijakan pembelajaran jarak jauh dirasakan masih belum sesuai dengan harapan, terlepas dengan segala kelebihan dan kekuranganya. Dinamika yang dihadapi di masa Covid 19 ini oleh pendidik maupun peserta didik serta orang tua menjadi tantangan tersendiri bagi pemerintah. Kolaborasi antara institusi pendidikan, peserta didik dan orang tua sangat diperlukan demi suksesnya program ini. Imbas pembelajaran jarak jauh pada konteks pendidikan Islam sangat berpengaruh dalam proses pembentukan karakter dan penanaman nilai-nilai ke-Islaman. Stake holder dan semua pemangku kebijakan mesti mendorong kebijakan ini agar proses transformasi pembelajaran dapat berjalan baik, dengan memanfaatkan dan memaksimalkan hadirnya teknologi informasi dan komunikasi yang tersedia.

Kata-kata Kunci: Pembelajaran jarak jauh, covid-19 dan pendidikan Islam. 


\section{Introduction}

Education is one of the epistemology sources in obtaining knowledge. Education is the efforts to promote the growth of children's character, mind and skills in life perfection context and harmony with the world. ${ }^{1}$ Education aims to develop the potential of students to become human beings who believe and also have devotion to God Almighty, healthy, knowledgeable, capable, noble, creative, independent and also democratic and responsible citizens. $^{2}$

The urgency of education in increasing social, cultural, moral and religious values which are useful for preparing students to face the challenges of the times which include the world of work, bureaucracy, technology and information and being able to adapt to real life where they live without losing their identity and existence as a noble human being.

The urgency of education was slightly disturbed by the emergence of the Covid-19 pandemic outbreak at the end of 2019 and early 2020. The corona virus is a large family of viruses that cause Middle East Respiratory Syndrome (MERS), Severe Acute Respiratory Syndrome (SARS) and Coronsvirus Desease2019 (COVID-190). In 2002 SARS first broke out in China and in 2012 first appeared in the Middle East. The existence of a new disease in China called Covid-19 has caused many deaths in various countries. $^{3}$

Since the World Health Organization (WHO) announced that a pneumia case in the city of Wuhan, Hubei Province in China was identified as a Coronavirus Disease (Covid-19) pandemic ${ }^{4}$, the Indonesian government has implemented several policies including learning and working from home (learn and work from home), social and physical distancing, shifting the Eid holidays to Large Scale Social Restrictions (PSBB).

This virus outbreak has not only physically attacked human immunity on earth but has also weakened human existence psychologically. The implication can destroy the joints of the community's economy, including the world of education. After the spread of this virus the government through the Ministry of Education and Culture has issued a Circular No. 4 concerning Implementation of Education Policies in an Emergency Period of the Spread of the Covid-19 virus, starting March 24, 2020. With the issuance of this p. $14-15$.

${ }^{1}$ Ki hajar Dewantara, Karja I Pendidikan, Jogjakartan: Pertjetakan Taman Siswa, 1962,

2 Undang-undang RI No. 20 tahun 2003, Tentang sistem Pendidikan Nasional, Pasal:3. http://simkeu.kemendikbud.go.id/index.php/peraturan1/8-uu-undang-undang/12-uu-no20-tahun-2003.

3 Amalia, L., Irwan, Hiola, F, Analisis Gejala Klinis dan Peningkatan Kekebalan Tubuh Untuk Mencegah Penyakit Covid-19, Jambura Journal of Health Sciences and Research, Vol. 2, No. 2, July 2020.

4 Sohrabi, C, Alsafi, Z., O'Neil, N., Khan, M., Kerwan, A., Al-Jabir, Losifidis, C., Agha, R, Word Health Organization Declares Global Emergency: A Review of the 2019 Novel Coronavirus (COVID-10), International Journal Of Surgey, Vol. 76, 2020, p. 71-76. 
circular, all education agencies took quick steps in responding to anticipate the spread of Covid-19 and implementing learning which all turn in-person learning to online learning. 5

The circular letter is in line with the regulation of the Minister of Education and Culture of the Republic of Indonesia number 119 of 2014 concerning the implementation of long distance education at the primary and secondary education levels as well as the regulation of the Minister of Education and Culture of the Republic of Indonesia number 24 of 2012 concerning the implementation of online education in Higher Education. Then it was followed up with the Decree of the Minister of Education and Culture of the Republic of Indonesia number 719 p / 2020, regarding guidelines for implementing curriculum in educational units in special conditions. ${ }^{6}$

Long distance education as referred to in the regulation is an education model in which the learning system is implemented remotely (distance learning). Educators and students are separated or they are not in one place when carrying out the learning process. This system utilizes online learning media (in the network) of the internet. Various media and learning resources that can be used by educators and students in this distance learning, for example the WA group, Messenger, Zoom Meeting, Google Class Room and so on.

The implementation of this distance learning program is adjusted to the environmental conditions of the education unit and according to the agreement of the related parties; Principals, Educators / Teachers and education personnel, students, parents, school committees, Covid-19 forces unit, local officials to the education office and regional heads. The elements involved in making this policy can synergize in determining online or offline learning models or even a combination of online and offline which is called a blended combination.

Terkait dengan permasalahan ini, kemudian muncul pertanyaan apakah pelaksanaan pembelajaran jarak jauh ini sudah sesuai dengan harapan, Mengingat implementasi peraturan Menteri tentang pembelajaran daring di lapangan ternyata masih banyak ditemukan kendala dan persoalan teknis dalam pelaksanaanya. Kemudian apa kelebihan dan kekurangan dari pembelajaran jarak jauh ini, Mengingat setiap penerapan program dari kebijakan publik pasti mengandung plus minus. Kemudian yang terakhir apa imbas pelaksanaan pembelajaran daring ini terhadap Pendidikan Islam.

In connection to this problem, then the question arises whether the implementation of this distance learning has met expectations. Given the implementation of Ministerial regulations regarding online learning in the field, there are still many obstacles and technical problems in its

5 Henry Aditia Rigianti, Kendala Pembelajaran Daring Guru Sekolah Dasar di Kabupaten Banjarnegara, Elementary School, Vol. 7, No. 2, 2020, p. 297.

${ }^{6}$ https://www.kemdikbud.go.id/main/files/download. 
implementation. Then what are the advantages and disadvantages of online learning, considering that every program implementation of public policy must have their own advantages and disadvantages. Then finally what is the impact of implementing this online learning on Islamic Education.

The implementation of this online learning should not only abort duties and obligations, but more than that it requires seriousness and seriousness from all elements, both from the government, education units and the wider community. The state as a facilitator must be present to monitor the journey of this long distance learning program and the community as users must play their role to success this program.

\section{The Concepts and the Definition of Online Learning}

The concept and meaning of long distance learning or known as virtual learning / distance education is learning that is designed remotely. There is a separation of places among educators and students but meet in cyberspace by utilizing internet communication technology and information facilities. According to Ibrahim, online learning has long been known in history, since human civilization since $1870^{7}$. The system used at first was only through correspondence and print media. Then it developed more by using radio and TV. Today, this longdistance learning system has become increasingly sophisticated by using the internet.

Some experts express this definition of online learning, such as G. Dogmen said that the characteristics of online learning are the existence of an organization that regulates independent learning, learning material is delivered through the media and there is no direct contact between educators and students. Mackenzie, Christensin and Righby said that long distance learning is a learning method that uses correspondence as a means of communication between instructors and learners. Long distance learning or online learning is a learning activity that utilizes a network (internet, LAN, WAN) as a method of delivery, interaction, facilities and is supported by various other forms of learning services ${ }^{8}$.

National Education System Law number 20 of 2003 article 1 paragraph 15 states that "Long distance education is education in which students are separated from educators and their learning uses various learning sources through communication technology, information and other media". Meanwhile, according to the regulation of the Minister of Education and Culture of Indonesia Republic No. 24 of 2012 article 1 concerning the Implementation of Long Distance Education in Higher Education, namely Distance Education or PJJ is education where students are separated from educators and their learning by using various learning sources both through information and communication technology (ICT) and other media. The

\footnotetext{
${ }^{7}$ Nurdin Ibrahim, ICT untuk Pendidikan terbuka Jarak Jauh, jurnal Teknodik, 2005, p. $5-18$.

8 Waryanto, NH, Online Learning Sebagai Salah Satu Inovasi Pembelajaran, Jurnal Matematika, Vol. 2, No.1, 2006, p.12.
} 
concept of PJJ has actually been used in tertiary institutions, especially those that have an Open University (UT) program, but for the early, primary and secondary education levels this is the first time to use this system. ${ }^{9}$

\section{The Online Learning Goals and Principles}

The purpose of online learning is to provide the widest possible opportunity for students to obtain education at all types, pathways and levels independently by using various learning resources and programs that are in accordance with the characteristics, the needs and the conditions of their environment. Thus, the purpose of online learning is essentially to provide educational opportunities to people who cannot follow conventional inperson learning ${ }^{10}$.

The purpose of online learning during the Covid-19 pandemic is to facilitate the fulfillment of students' needs for education. This online learning is an alternative to offline or in-person learning in classrooms, which during this pandemic cannot be implemented as usual. Whereas the principles of long distance education are the principles of freedom, independence, flexibility, contemporaryity, suitability, mobility, and efficiency. These principles are an important basis in making policies related to the implementation of distance learning ${ }^{11}$.

The principle of long distance learning (online) can be described as follows: a) The principle of freedom, which means that the education system is democratic, free to be accessed by anyone; b) The principle of independence; the existence of a curriculum or program that can be studied independently (independent learning), individual or collective learning; c) The principle of flexibility, learners can organize their own learning activities according to their ability; d) The principle of suitability, the existence of a learning program that is relevant to the needs of students and according to their interests and abilities; e) The principle of mobility; students can move places according to their conditions for the learning process or continue to a higher level; f) The principle of efficiency, which is to optimally the use of human and technological resources.

\section{The Characteristics of Online Learning}

According to Michael Simonson in the Britanica article, there are four characteristics that distinguish long distance learning from in-person learning. They are being implemented by an institution, secondly there is a separation of distance and time between students and educators, thirdly

\footnotetext{
${ }^{9}$ Frida Rohmyani, Kelebihan dan Kekurangan PJJ di Masa Pandemi Covid 19, dalam Kumparan, https://kumparan.com/frida-rohmyni/kelebihan-dan-kekurangan-pjj-di-masapandemi. 25.

10 Munir, Pembelajaran Jarak Jauh Berbasis Teknologi, Informasi dan Komunikasi, p. 11 Ibid.
} 
there is interactive telecommunications that connects fellow students with educators, finally there is a study group consisting of students, educators and instructional resources such as books, audio, video and graphic displays that allow students to access instructional content on the internet network. Meanwhile, according to Warsito, the characteristics of distance learning include: there is separation between educators and students as well as fellow students during the learning process, there is an agency that manages its educational programs and the availability of technology, information and communication facilities. ${ }^{12}$

Meanwhile, according to Dr. Munir among the characteristics of distance learning are as follows: ${ }^{13}$ a) The program is adjusted to the level, type and nature of education; b) There is no meeting or direct contact in the learning process between students and educators, except for certain things; c) The existence of an educational institution that regulates students to learn independently; Learning institutions design and prepare learning materials and assistance services to students; d) Learning material is delivered through learning media such as the internet and other audio-visuals; e) Students are required to be active, interactive and participatory in the learning process; f) Learning resources are developed deliberately according to the needs based on the curriculum.

\section{The Considerations for the application of Long-Distance Learning}

The Covid-19 pandemic has paralyzed or at least nourished various important activities in human life, starting from small social interactions (family), society, countries and even the whole world, all of which have the potential to be affected by the outbreak of this virus, including the world of education.

Education is one of the institutions that has been affected seriously, many schools have closed because they do not want to be targets of this viral tantrum. This condition requires educational institutions to innovate and be creative in the learning process. As the circular of the Ministry of Education and Culture (Kemendikbud) No.4 of 2020 concerning the implementation of Education policies in the emergency period of the spread of Covid-19 related to the learning process states that learning from home through online / long distance learning is carried out to provide meaningful learning for students ${ }^{14}$.

Therefore, the Ministry of Education and Culture then took a policy and instructed all educational institutions from the early childhood education level to tertiary institutions to temporarily stop in-person learning activities

\section{1.}

12 Warsito, Peran TIK dalam Penyelenggraan PJJ, Jurnal Teknodik, No. 20, 2007, p. 9-

${ }_{13}$ Munir, Pembelajaran Jarak Jauh Berbasis Teknologi, Informasi dan Komunikasi, p. 29-30.

${ }^{14}$ Ahmad Jayul dan Edi Irwanto, Jurnal Pendidikan Kesehatan Rekreasi, Vol. 6, No. 2, p. 190-191. 
and divert them to long distance learning (online). This is done as an effort to avoid direct contact between educators and students in a face-to-face system so that it can break the chain of spreading Covid-19. The Indonesian government through the Ministry of Education and culture and the Ministry of Religion of the Republic of Indonesia has implemented a policy of learning and working from home (work from home) since mid of March 2020.

This online learning policy has actually been issued for a long time, because it is considered as learning that is relevant to the era of the industrial revolution 4.0. However, this policy is not widely used by managers of educational institutions for various reasons that arise, ranging from technical implementation to the lack of human resources and learning resource facilities or available media. However, along with the outbreak of the Covid 19 outbreak, whether willing or not and ready to be unprepared, this virus seems to have forced all parties to immediately implement long distance learning, which was still debatable among experts in terms of its application.

The government has issued various policies and initiatives in dealing with learning constraints during the Covid-19 pandemic, such as the revision of the Joint Ministerial Decree issued on 7 August 2020, to adjust the learning policy during the pandemic. The main purpose of implementing this distance learning is to avoid the crowd (social distancing), in order to cut the chain of spreading the Covid-19 virus.

\section{The Plus Minus and Implementation of Distance Learning}

Every program that functions as an alternative in overcoming or finding solutions to problems that become public policy will certainly reap pros and cons in its implementation and it certainly also has its advantages and disadvantages, including the case with the policy of implementing this longdistance learning system, called in Indonesia Pembelajaran Jarak Jauh or PJJ.

Munir in Bates and Wulf, states that there are four advantages of PJJ: ${ }^{15}$ (a) Increase learning interaction (enhance interactivity). Long distance learning or online learning, if implemented properly will be able to increase the level of interaction between students and educators, students with learning materials and between students and other students. Students are automatically required to be active and independent in learning; (b) Facilitating learning interactions from anywhere and at any time (time and place flexibility). Students can interact with learning resources anytime and anywhere according to the time available, because learning resources have been packaged electronically and can be accessed through online learning, (c) It has a wider reach (potential to reach global audience). Long distance learning through online is more and more widely open, accessible to anyone and anytime and anywhere, because time and space boundaries are no longer an obstacle to learn. This broad reach can add broad insights for students; (d) Facilitate the improvement and storage of learning materials (easy updating

${ }^{15}$ Munir, Pembelajaran Jarak Jauh Berbasis Teknologi, Informasi dan Komunikasi. 
of countent as well as archivable capabilities), online learning technologies and other developing software facilitate the development of learning materials as well as electronic data storage, so that at any time it can be changed or done, evaluated and updated ${ }^{16}$.

In addition, the advantages of long distance learning can also save costs, especially for students, only with the internet data package; they can participate in learning without worrying about missing lessons if they cannot attend. ${ }^{17}$ Meanwhile the shortcomings of this distance learning system include: 1) Lack of interaction, because they cannot meet directly with their teachers, it can hinder the formation of attitudes, values, morals and social in the learning process: 2) Technology is an important part of online learning, too focused on technology will potentially more inclined to technical or commercial aspects only and not on aspects of education; 3) The learning process tends towards training rather than education, and focuses on cognitive and psychomotor aspects rather than affective; 4) Limited internet access; in certain areas, especially 3T areas (disadvantaged, frontier, outermost), this online learning method is deemed ineffective because of the difficulty of getting network access (internet signal); 5) Understanding on the material; the level of ability of students' understanding of various learning materials will affect the absorption of the material presented by the educator. This will lead to potential failure for inactive learners; 6) Lack of supervision in learning, lack of direct supervision from parents or educators can cause students to lose focus. The ease of access sometimes make students tends to delay study time. ${ }^{18}$

\section{The Implementation of Online Learning}

The long distance learning system during this pandemic shocked people, both education managers, students, and parents / students' guardians. A variety of responses then appeared varied, either they welcomed them well, were forced or even confused with this system. As for educational institutions that are advanced and accustomed to use ICT before the pandemic, it will be easier to follow this system. On the other hand, educational institutions that are not yet developed and classified as middle and lower class will find it difficult to follow because infrastructure support and human resources and natural resources facilities have not been fulfilled.

16 Munir, Pembelajaran Jarak Jauh Berbasis Teknologi, Informasi dan Komunikasi, p. 217-218.

17 http://www.wantiknas.go.id/id/berita/empat-kelebihan-dan-kekurangan-dalammenerapkan-e-learning.

18 http://www.wantiknas.go.id/id/berita/empat-kelebihan-dan-kekurangan-dalammenerapkan-e-learning 
Referring to circular number 4 of 2020 point 2, there are four discussions about the learning process from home: ${ }^{19}$ a) The learning process from home through online is carried out to provide meaningful learning experiences for students without being burdened with the demands to complete all curriculum achievements for class promotion and graduation; b) Learning from home can be focused on life skills education, including regarding the COVID-19 pandemic; c) Learning activities and assignments from home can vary according to the interests and conditions of students and taking into account gaps in access / learning facilities from home; d) Evidence or product of learning activities from home is given feedback from the teacher which is qualitative and useful without giving a score / quantitative value.

If it is seen from this circular, educators are required to be able to innovate and be creative in creating learning that is fun and easily accepted by students, meanwhile, the teaching human resources are not all of the quality as expected. As Syahran quoted ffrom Prayitno, that the low quality of teacher as human resources was due to the non-practice of educational science and the rampant accidents of education. ${ }^{20}$

Even though the Ministry of Education and Culture has created a website on online learning guides, due to the lack of socialization, ultimately it does not reach the educators optimally. The lack of socialization of online learning causes educators to carry out the long-distance learning process in their own way. If the Educational Institution is advanced and the learning facilities are fulfilled, of course, it will be easy to make regulations on distance learning centered on a single portal created by the Educational Institution. Conversely, if the educational institution is still underdeveloped and lacking support from advanced human resources and adequate facilities, then the institution will of course submit the learning system to each educator, so that educators usually only assign tasks every day as a formality to follow government policies.

The methods or online learning media that are often used by educators are as follows: WhatsApps (WA), Google Form, Google Classroom, Google Drive, Youtube, WA Group, and some even use the Zoom Meeting and Video Call applications.

Barriers that often arise in online learning, according to Andri Anugraha's research ${ }^{21}$, include: Students do not have devices (Android phones), Signal is less supportive, limited quota, cellphones are often used by their parents so that they are not on time to complete their tasks. In addition,

19 https://www.kelaspintar.id/blog/edutech/plus-minus-sistem-pembelajaran-jarakjauh-di-indonesia-6166/

20 M. syahran Jailani, Guru Profesional dan Tantangan Dunia Pendidikan, Jurnal AlTa'lim, Vol. 21, No.1, 2014, p. 3.

${ }^{21}$ Andi Nugraha, Hambatan, Solusi dan Harapan: Pembelajaran Daring Selama Masa Pandemi Covid-19 Oleh Guru Sekolah Dasar, Scholaria, Jurnal Pendidikan dan Kebudayaan, Vol 10, No. 3. 2020, p. 285. 
obstacles to educators include the lack of ability of educators to use a variety of learning methods and the lack of ability of educators to make fun learning modules.

The constraints often faced by teachers / educators according to the results of research by H.A. Riganti are as follows ${ }^{22}$ : (a) This learning application that seems so sudden has forced educators to use the internet as the only means of delivering material. This is a separate obstacle for educators because there is no readiness from both school and the education office in the form of training on the use of online learning applications; (b) Internet Networks and Devices the need for an internet connection is very important in implementing online learning, however the facts in the field prove that the internet signal network is still not strong; (c) Learning Management or the ability to manage learning is an absolute requirement for an educator in sequencing the material presented logically. According to Mulyasa this ability consists of two stages, namely selecting learning materials and arranging learning materials; ${ }^{23}$ (d) Learning Assessment which has constraints in terms of assessing the completeness of student learning related to honesty in solving questions. If you get the maximum score, it is not certain that the students have understood the learning material because it could be someone else doing it; (e) Lack of supervision from educators and parents is an important condition in the success of online learning. But in reality parents are too busy with activities. Even though according to Nadim Makarim (Minister of Education and Culture), the collaboration between parents and teachers is very important in supporting the success of online learning during this pandemic. ${ }^{24}$

Meanwhile, the obstacles that are often experienced by students according to Syafaruddin's research are they do not have device or cellphone and not having an internet quota. ${ }^{25}$

\section{The Online Learning Constraints}

According to Asmuni there are three constraining factors in online learning ${ }^{26}$, educator, students and parent factors. The constraints of this educator factor include: First, the content of the material presented by the Educators may not necessarily be understood by students. The proposed solution is that

22 Henry Aditia Rigianti, Kendala Pembelajaran Daring Guru Sekolah Dasar di Kabupaten Banjarnegara, https://journal.upy.ac.id/index.php/es/search/authors

${ }^{23}$ Mulyasa, Pengembangan dan Implementasi Kurikulum 2013, Bandung: PT. Remaja Rosdakarya, 2013, p. 139.

$24 \quad$ https://www.kompas.com/edu/read/2020/05/03/092749071/diskusimendikbud

25 Syafaruddin, Aplikasi Pembelajaran Daring Yang Digunakan Oleh Guru Sekolah Dasar Negeri 151/IV Alam Barajo Kota Jambi, Skripsi, UIN STS Jambi, 2020.

${ }^{26}$ Asmuni, Problematika Pembelajaran Daring di Masa Pandemi Covid-19 dan Solusi Pemecahannya, Jurnal Paedagogy: Jurnal Penelitian dan Pengembangan Pendidikan, Vol.7, No.4, 2020. 
educators try to prepare learning materials as attractive as possible, for example with power points accompanied by learning videos, the existence of learning modules, LKPD and other learning applications. Second, the limitations of educators in using technology, the solution is to use simple and easy to use technology, for example WhatsApp, or study with peer educators. Third, the limitations of educators in monitoring learning, the solution is for students who are less concerned with learning and do not allow home visits to be contacted directly via cell phones.

There are obstacles for students; first, not having an Android device, the solution is that students can do assignments manually. If possible once a week students submit their assigments to their teacher and if it is not possible, they can join with their closest friends who have an android to study together. Second, students do not have internet access; the solution is if, because there is no credit, they can do thethering to family members and if because the signal, they can search for areas / places where the signal is available. Third, students are lazy and bored, the solution is that educators work with the BK or the principal to contact their parents so they can participate in monitoring and motivating children.

Meanwhile, the obstacle from parents is usually parents are too busy with their work and the increasing economic burden of the family due to the pandemic or because of online learning that has to buy internet data packages. The solution is that the school contacts the students' parents and asks for their cooperation in making distance learning successful and providing a special data package for learning.

\section{The Impact of Distance Learning Policy on Islamic Education}

There are several positive and negative impacts of distance learning policies via the internet or online, ${ }^{27}$ the positive impact is, for example, students can have a lot of time with family, students gain learning experiences using various learning methods, students are not technologically illiterate. While some of the negative impacts include: students are threatened with dropping out of school because they have to help the family economy, the decreasing learning achievement and quality, limited devices and internet quotas as the learning support, lack of social interaction of students because they are too busy with their devices and students are free to access the internet without supervision from parents. Apart from the positive and negative impacts of online learning on education, the author will focus more on the impact of online learning on Islamic Education.

This long distance learning or online system will more or less have an impact or effect on the world of education, especially on the quality of graduates. The success or failure of an education is measured by the achievement of educational goals through the learning process.

\footnotetext{
27 https://metro.tempo.co/read/1391861/dampak-negatif-dan-positif-pembelajaranjarak-jauh-selama-pandemi-covid-19.
} 
The experts define education with various perspectives. Poerwadarminta defines education a a noun which means the process of changing the attitudes and behavior of a person or group of people in an effort to mature humans through learning and training ${ }^{28}$. This definition explicitly states that the purpose of education is essentially to change the students' attitute to become adults. The word education is a form of a noun where the verb is to educate, so to educate is a job done by an educator both in the small environment (family) and in the largest environment (Educational Institution).

Zahari Indris said that Education is a series of communication activities aimed at making educators and students meet face-to-face or by using the media in order to provide assistance in the development of children as a whole. ${ }^{29}$ This opinion confirms that the distance learning system is another option for in-person learning that cannot be implemented due to the Covid19 pandemic.

Meanwhile, according to Dwi Rahmawati, education in Islam perspective is to educate someone physically, spiritually, intellectually, heart and morally as well as skills so that they can face their environment with all its good and evil ${ }^{30}$. This definition further clarifies the function and purpose of Education in Islam according to al-Ghozali, quoted by Abudin Nata, that the purpose of Islamic Education is to get closer to Allah SWT, not to seek a position that generates money, because education that is directed not to get closer to Allah will generate envy, hatred and enmity 31 . The purpose of this education is then further elaborated into three main ideas. First, studying science as a form of worship to Allh SWT, second: as a means of forming alKarimah morals, third: taking students to achieve happiness in the world and the hereafter. ${ }^{32}$

Although formally this education activity can be carried out online, character education as the goal of education defined by al-Ghozali is still less intensive if the level of success is measured. Education carries out in online learning is more about knowledge transfering educating children's character. The character education that has been carried out at schools with direct supervision from educators cannot be done through online learning. The Islamic character building program by implementing religious activities such as reciting the Qur'an, muhadhoroh, congregational prayer cannot be carried out during online learning. Even though there are schools that make

${ }^{28}$ Hasan Basri, Landasan Pendidikan, Bandung: Pustaka Setia, 2013, p. 14.

29 https://www.gurupendidikan.co.id/pengertian-pendidikan/, downloaded on 09012021.

${ }^{30}$ Resti Sekar Hanisa dan Suryadi, Dampak Pembelajaran Daring Terhadap Perilakuperilaku Religius di Tengah Situasi Social Distancing Akibat Pandemi Covid-19, Al-Ulya Jurnal Pendidikan Islam, No. 2, 2020, p. 233.

${ }^{31}$ Abuddin Nata, Filsafat Pendidikan Islam, Jakarta: Gaya Media Pratama, 2005. p. 159160.

${ }^{32}$ Al-Rasyid dan Samsul Nizar, Filsafat Pendidikan Islam, Jakarta: Ciputat Press, 2005, p. 91. 
reporting mechanisms for worship activities at home, the direct presence of educators is still very much needed for the implementation of comprehensive character education.

Exemplary educators directly in educational institutions are one of the the successful factors in character education. Especially during the Covid-19 period, parents were busy working as an effort to organize the family economy so that they can not pay attention to their children's learning, sometimes even involving their children to help with their work during study hours.

Many factors cause the concept of education in the family which has not been practiced optimally. Syahran explained that ${ }^{33}$ 1) Lack of knowledge and understanding of parents regarding the roles and functions and responsibilities of children's education at home. This could be due to the low level of the parents' education; 2) Weak socio-cultural role of the community in building awareness of the importance of family education; 3) The strong economic pressure of parents in meeting the demands of family needs, so that sometimes they neglect their role as educators in the family; 4) The advancement of information technology affects the mindset of parents, for example providing media facilities to children without control, because of the lack of the parents attention.

Many educators have complained about the level of participation of students in doing assignments while learning online for various reasons. For example, they do not have an Android device, no internet signal, and they do not understand the learning material and so on. In the evaluation process there are also many difficulties faced, for example the level of honesty in working on exam questions because it is without direct supervision from the educators.

There are several impacts of this online learning on Islamic Education. The positive impacts are: 1) Increasing the awareness of learning Islamic Education applications; 2) Increasing the quality of worship in facing disaster; 3) Raising people's awareness of the importance of maintaining health: 4) Reminding people of their weaknesses in the presence of the Most Strong and Powerful Allah SWT; 5) Minimizing the students and educators risk at spreading the Covid-19 virus. ${ }^{34}$ Meanwhile, the negative impacts are: 1) Lack of friendship, especially among Muslims, generally among people 35 . 2) The absence of Islamic education activities in mosques 3) Gadget addiction makes children out of control, forgets time and neglects religious obligations; 3) Decreasing social interactions, because students are busy with their own gadgets; 4) Obstruction of the implementation of Islamic character education.

\footnotetext{
${ }^{33}$ M. Syahran Jailani, Teori Pendidikan Keluarga dan Tanggungjawab Orang Tua dalam Pendidikan Anak Usia Dini, Nadwa: Jurnal Pendidikan Islam, Vol. 8, No. 2, 2014.

34 Yunus, N. R., \& Rezki, A, Kebijakan Pemberlakuan Lock Down Sebagai Antisipasi Penyebaran Corona Virus Covid-19, SALAM: Jurnal Sosial Dan Budaya Syar-i, 2020.

35 Nurullita Al-Munawaroh, Dampak Lockdown Covid 19 Pada Pendidikan Islam di Indonesia, ATTA’DIB: Jurnal Ilmiah Prodi Pendidikan Agama Islam, Vol.12, No.2, 2020.
} 
It is feared that online learning which has been enforced for too long due to the Covid-19 pandemic because it is accustomed to the ease of internet access with minimal parental control and free access to internet sites that give students the opportunity to access non-educational content, online games, online gambling. or special "eighteen plus" sites in which a lot of pornography and action porn are shown. On the other hand, if the Covid-19 pandemic can be used optimally by students, parents and educators by planning an interesting learning, there will be an increase in the formation of students' character values in five ways; inculculating religious character values, disciplinary character, creative character, independent character, and responsibility character. ${ }^{36}$

The Indonesian nation, especially the world of education, will have no shortage of smart and intelligent people in this internet era. Access to information and communication for learning is easily obtained anytime and anywhere. Learning that is only based on the knowledge transfer will not be able to change the dignity of a nation, because it will only create intelligent generation but crisis in moral. However, education that is oriented towards character building will give birth to the nation's children who are not only intelligent but also have noble characters or morals.

\section{Closing}

Coronavirus Disease 19 or the Covid-19 virus has become a trending topic at the beginning of 2020. This is not because of the greatness of this virus, but the impact it causes to make the inhabitants of the earth all over the country fully alert to anticipate its spread which not only threatens human lives but also changes life style and human life order. More or less, the emergence of this virus has positive and negative impacts for mankind, especially on the world of education, which is the spirit of life.

Learning, which has relied on in-person models, inevitably has to be switched to online system learning (distance learning) or what is commonly called distance learning (PJJ) or online (online). This policy is an effort to cut the chain of the spread of Covid-19 by avoiding the crowds (social distancaing). The application of Working and Learning From Home and in its implementation has resulted in many problems and obstacles. Starting from the inadequate readiness of educational institutions, inadequate human resources, incomplete learning facilities, including uneven internet networks, to less than optimal collaboration between educators, students and parents, apart from the positive value of distance learning itself such as convenience, access to learning anytime and anywhere, efficiency of education costs for students, increasing IT knowledge and so on.

36 I Putu Yog Purndina dan I Made Astra Wijaya, Pendidikan Krakter di Lingkungan Kelurg selama Pembelajarn Jarak Jauh pada Masa Pandemi Covid-19, Jurnal Ilmu Pendidikan, Vol.3, No.2, 2020, p. 279-283. 
The implementation of this online learning also has an impact on Islamic Education either directly or indirectly. The character building program or religious habituation that usually can be directly monitored by educators is now no longer applicable. This condition causes students to lack control in the aspect of character building or akhlak al-karimah. It is worse by the weak supervision of parents who are busy with their activities in order to support the family economy.

\section{Bibliography}

Al-Munawaroh, Nurullita, Dampak Lockdown Covid 19 pada Pendidikan Islam di Indonesia, ATTA'DIB: Jurnal Ilmiah Prodi Pendidikan Agama Islam, Vol. 12, No. 2, Desember 2020.

Al-Rasyid dan Samsul Nizar, Filsafat Pendidikan Islam, Jakarta: Ciputat Press, 2005.

Amalia, L., Irwan, Hiola, F, Analisis Gejala Klinis dan Peningkatan Kekebalan Tubuh untuk Mencegah Penyakit Covid-19, Jambura Journal of Health Sciences and Research, Vol. 2, No. 2, 2020.

Basri, Hasan, Landasan Pendidikan, Bandung: Pustaka Setia, 2013.

Dewantara, Ki hajar, Karja I Pendidikan, Jogjakarta: Pertjetakan Taman Siswa, 1962.

Hanisa, Resti, Sekar dan Suryadi, Dampak Pembelajaran Daring Terhadap Perilaku-perilaku Religius di Tengah Situasi Social Distancing Akibat Pandemi Covid-19, Al-Ulya Jurnal Pendidikan Islam, No. 2, 2020.

http://udinharun.lecturer.pens.ac.id/pjj/docs/2012\%20\%20Permendikbud \%20No\%2024\%20Tahun\%202012\%20Tentang\%20Penyelenggaraa n\%20Pendidikan\%20Jarak\%20Jauh\%20PJJ\%20Pada\%20Pendidikan \%20Tinggi.pdf,

http://www.wantiknas.go.id/id/berita/empat-kelebihan-dan-kekurangandalam-menerapkan-e-learning

https://metro.tempo.co/read/1391861/dampak-negatif-dan-positifpembelajaran-jarak-jauh-selama-pandemi-covid19/full\&view=ok.unduh

https://www.gurupendidikan.co.id/pengertian-pendidikan/.

https://www.kelaspintar.id/blog/edutech/plus-minus-sistem-pembelajaranjarak-jauh-di-indonesia-6166/,unduh

https://www.kemdikbud.go.id/main/files.

https://www.kompas.com/edu/read/2020/05/03/092749071/diskusimendikbud-dan-najwa-shihab-ini-dampak-positif-negatif-coronadi?page $=$ all,

Ibrahim, Nurdin, ICT untuk Pendidikan Terbuka Jarak Jauh, Jurnal Teknodik, No. 16, 2005, hlm. 5-18. 
Jailani, M. S, Teori Pendidikan Keluarga dan Tanggungjawab Orang Tua dalam Pendidikan Anak Usia Dini, Nadwa: Jurnal Pendidikan Islam, Vol. 8, No.2, 2014.

Jailani, M. Syahran, Guru Profesional dan Tantangan Dunia Pendidikan, Jurnal Al-Ta'lim, V. 21, No.1, 2014.

Jayul, Ahmad dan Edi Irwanto, Jurnal Pendidikan Kesehatan Rekreasi, Vol 6, No. 2.

Mulyasa, Pengembangan dan Implementasi Kurikulum 2013, Bandung: PT. Remaja Rosdakarya, 2013.

Munir, Pembelajaran Jarak Jauh Berbasis Teknologi, Informasi dan Komunikasi, Bandung: Alfabeta, 2009.

Nata, Abudin, Filsafat Pendidikan Islam, Jakarta: Gaya Media Pratama, 2005.

Nugraha, Andi, Hambatan, Solusi dan Harapan: Pembelajaran Daring Selama Masa Pandemi Covid-19 Oleh Guru Sekolah Dasar, Scholaria: Jurnal Pendidikan dan Kebudayaan, Vol. 10, No. 3, 2020.

Purandina, I Putu Yoga dan Wijaya I Made Astra, 2020, Pendidikan Krakter di Lingkungan Kelurga selama Pembelajarn Jarak Jauh pada Masa Pandemi Covid-19, JurnalImuPendidikan, Vol. 3, 2021.

Rigianti, Henry Aditia, Kendala Pembelajaran Daring Guru Sekolah Dasar di Kabupaten Banjarnegara.

Rohmyani, Frida, Kelebihan dan Kekurangan PJJ di Masa Pandemi Covid 19, dalam Kumparan, https://kumparan.com/frida-rohmyni/kelebihandan-kekurangan-pjj-di-masa-pandemi-covid-191tfqW5fo82o/full,unduh 05-01-2021.

Simson, Michael, Distance Learning, Artikel Britanica, 2021.

Sohrabi, C., Alsafi, Z., O’Neil, N., Khan, M., Kerwan, A., Al-Jabir, Losifidis, C., Agha, R, Word Health Organization Declares Global Emergency: A Review of The 2019 Novel Coronavirus COVID-10, International Journal Of Surgey, Vol. 76, 2020.

Syafaruddin, Aplikasi Pembelajaran Daring Yang Digunakan Oleh Guru Sekolah Dasar Negeri 151/IV Alam Barajo Kota Jambi, Skripsi, Prodi Pendidikan Guru Madrasah ibtidaiyah Fakultas Tarbiyah dan Keguruan UIN Sulthan Thaha SaifuddinJambi, 2020.

Undang-undang RI No. 20 tahun 2003, Tentang sistem Pendidikan Nasional, Pasal: 3. http://simkeu.kemendikbud.go.id/index.php/peraturan1/8uu-undang-undang/12-uu-no-20-tahun-2003-tentang-sistempendidikan-nasional.

Warsito, Peran TIK dalam Penyelenggraan PJJ, Jurnal Teknodik, No. 20, 2007.

Waryanto, NH, Online Learning Sebagai Salah Satu Inovasi Pembelajaran, Jurnal Matematika, Vol. 2, No.1, 2006.

Yunus, N. R., \& Rezki, A, Kebijakan Pemberlakuan Lock Down Sebagai Antisipasi Penyebaran Corona Virus Covid-19, SALAM: Jurnal Sosial Dan Budaya Syar-I, 2020 